\title{
Heterófilos em sangue periférico de Phrynops geoffroanus (Testudines: Chelidae) de ambiente urbano na região noroeste do estado de São Paulo
}

\section{Heterophils in peripheral blood of Phrynops geoffroanus (Testudines: Chelidae) from an urban environment of the northeast region of São Paulo State}

\author{
Carlos E. S. Zago ${ }^{1}$ \\ Sebastião R. Taboga ${ }^{2}$ \\ Claudia R. Bonini-Domingos ${ }^{3}$
}

Os heterófilos são formas celulares acidófilas encontradas em aves e répteis, com predominância no gênero Squamata. Ao microscópio de luz são similares aos eosinófilos e, muitas vezes, equivocadamente assim identificados, mas apresentam nítida diferença de granulação. ${ }^{1,2}$ A Figura 1 mostra a visualização de heterófilos (A) e eosinófilos (B) por microscopia de luz com evidência para a granulação. Em microscopia eletrônica de transmissão a granulação presente no citoplasma de heterofilos mostra a diversidade de grânulos (Figura 2). O aumento nos valores médios desse tipo celular pode indicar resposta do sistema imune frente a agentes bacterianos, fúngicos, virais e parasitários, como observado na contagem diferencial da série branca, em Phrynops geoffroanus de ambiente urbano, com valores médios aumentados de linfócitos, eosinófilos, heterófilos e azurófilos quando comparados com animais de criatório. ${ }^{3}$

\section{Referências Bibliográficas}

1. Goulart CES. Herpetologia, Herpetocultura e Medicina de Répteis. Ed. L.F. Livros de Veterinária Ltda, $1^{\circ}$ ed., p.21-56, 99-108, 131144,2004

2. Martínez-Silvestre A, Marco I, Rodriguez-Dominguez MA, Lavín, S, Cuenca R. Morphology, cytochemical staining, and ultrastructural characteristics of the blood cells of the giant lizard of El Hierro (Gallotia simonyi). Research in Veterinary Science. 2005;78:127-134.

3. Zago CES. Anatomia do aparelho reprodutor e hematologia de Phrynops geoffroanus (Testudines:Chelidae). Dissertação de Mestrado, Programa de Pós-Graduação em Biologia Animal - Instituto de Biociências, Letras e Ciências Exatas, Universidade Estadual Paulista, 2007, 92p.

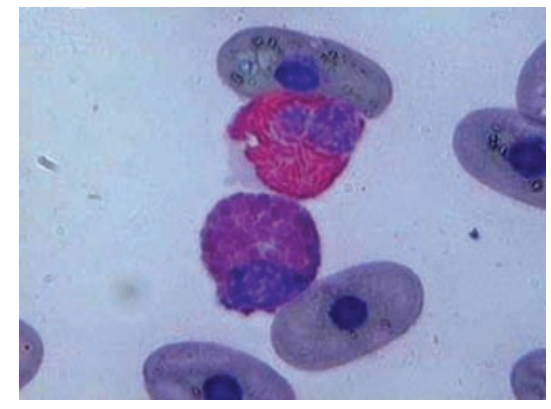

Figura 1. Fotografia obtida por microscopia de luz, de um heterófilo (A) e de um eosinófilo (B) de sangue periférico de Phrynops geoffroanus (Testudines: Chelidae)

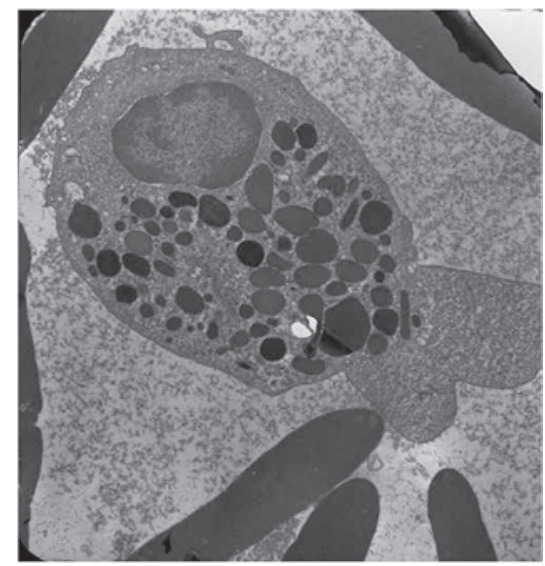

Figura 2. Imagem obtida por microscopia eletrônica de transmissão, evidenciando as características granulocíticas dos heterófilos

Suporte Financeiro: Capes

Avaliação: Editor e dois revisores externos Conflito de interesse: não declarado

Recebido: 07/01/2009

Aceito: 20/01/2009

${ }^{1}$ Médico veterinário. Unesp/Ibilce - Depto. de Biologia, Centro de Estudos de Quelônios - São José do Rio Preto- SP. ${ }^{2}$ Professor Livre-Docente. Unesp/Ibilce - Depto. de Biologia, Laboratório de Microscopia e Microanálise - São José do Rio Preto-SP. ${ }^{3}$ Bióloga. Unesp/Ibilce - Depto. de Biologia, Laboratório de Hemoglobinas e Genética das Doenças Hematológicas. Centro de Estudo de Quelônios - São José do Rio Preto-SP.

Trabalho realizado na Unesp - Centro de Estudos de Quelônios, Departamento de Biologia. São José do Rio Preto, SP

Correspondência: Claudia Regina Bonini-Domingos

Rua Cristóvão Colombo, 2265 - Jd. Nazareth

15054-000 - São Paulo-SP - Brasil

Tel.: (55 17) 3221-2392 -Email: bonini@ibilce.unesp.br

Doi: 